Article

\title{
Use of Antibiotics for Maintenance of Axenic Cultures of Amphidinium carterae for the Analysis of Translation
}

\author{
Chieh-Lun Liu, Allen R. Place and Rosemary Jagus * \\ Institute of Marine and Environmental Technology, University of Maryland Center for Environmental Science, \\ 701 E. Pratt Street, Baltimore, MD 21202, USA; liuh@umces.edu (C.-L.L.); place@umces.edu (A.R.P.) \\ * Correspondence: jagus@umces.edu; Tel.: +410-234-8822
}

Received: 17 April 2017; Accepted: 27 July 2017; Published: 1 August 2017

\begin{abstract}
Most dinoflagellates in culture are bacterized, complicating the quantification of protein synthesis, as well as the analysis of its regulation. In bacterized cultures of Amphidinium carterae Hulbert, up to $80 \%$ of protein synthetic activity appears to be predominantly bacterial based on responses to inhibitors of protein synthesis. To circumvent this, axenic cultures of $A$. carterae were obtained and shown to respond to inhibitors of protein synthesis in a manner characteristic of eukaryotes. However, these responses changed with time in culture correlating with the reappearance of bacteria. Here we show that culture with kanamycin $(50 \mu \mathrm{g} / \mathrm{mL})$, carbenicillin $(100 \mu \mathrm{g} / \mathrm{mL})$, and streptomycin sulfate $(50 \mu \mathrm{g} / \mathrm{mL})(\mathrm{KCS})$, but not 100 units $/ \mathrm{mL}$ of penicillin and streptomycin (PS), prevents the reappearance of bacteria and allows $A$. carterae protein synthesis to be quantified without the contribution of an associated bacterial community. We demonstrate that $A$. carterae can grow in the absence of a bacterial community. Furthermore, maintenance in KCS does not inhibit the growth of $A$. carterae cultures but slightly extends the growth phase and allows accumulation to somewhat higher saturation densities. We also show that cultures of $A$. carterae maintained in KCS respond to the eukaryotic protein synthesis inhibitors cycloheximide, emetine, and harringtonine. Establishment of these culture conditions will facilitate our ability to use polysome fractionation and ribosome profiling to study mRNA recruitment. Furthermore, this study shows that a simple and fast appraisal of the presence of a bacterial community in A. carterae cultures can be made by comparing responses to cycloheximide and chloramphenicol rather than depending on lengthier culture-based assessments.
\end{abstract}

Keywords: Amphidinium carterae; axenic cultures; bacterized cultures; antibiotics; protein synthesis inhibitors

\section{Introduction}

Amphidinium is a widespread dinoflagellate genus, found in temperate and tropical marine waters, in both free-living and endosymbiotic states. Amphidinium appears to be a relatively early evolving lineage of dinoflagellates based on phylogenetic studies of transcriptomes and contains the hallmark dinoflagellate plastid with peridinin pigment [1-4]. Amphidinium carterae Hubert represents the most well-studied dinoflagellate species and has begun to emerge as a "model" for dinoflagellates in research into dinoflagellate genetics, photosynthesis, and polyketide/toxin production (reviewed [5]). A. carterae Hubert grows well in culture to high cell densities, is available from culture collections, has a relatively small genome of about $5.9 \times 10^{9} \mathrm{bp}$ [6]. In addition, A. carterae is considered one of the new target species suitable for commercial exploitation on an industrial scale [7] since it shows resistance to mechanical stress in photobioreactors and because several high value metabolites can be extracted from it $[8,9]$. 
Dinoflagellates exhibit little transcriptional regulation of gene expression [10-13], but have been widely demonstrated to show changes in expressed proteins [14-19]. Post-transcriptional regulation of gene expression in dinoflagellates has focused on translational control and in particular on the regulation of mRNA recruitment [20-23]. All nuclear mRNA in dinoflagellates is trans-spliced with a 22-nucleotide $5^{\prime}$-spliced-leader sequence $[24,25]$. In A. carterae, the spliced leader RNA introduces a $\mathrm{m}^{7}$ Gppp cap structure at the $5^{\prime}$ end, any one of the four nucleotides at the second position and additional methylations on downstream bases to give novel multi-methylated caps [21]. Furthermore, eight family members of the cap binding translation initiation factor eIF4E, from three novel clades, have the potential to participate in, or regulate, mRNA recruitment in A. carterae [21,22].

Polysome fractionation by velocity centrifugation in sucrose gradients is a routine technique for examining the translating pool of ribosomes in a cell and has been used to monitor translational status under various physiological conditions (reviewed [26]). As the ribosome moves along the mRNA molecule during translation elongation, additional ribosomes can initiate translation on the same RNA molecule, forming polysomes. Since ribosome loading on mRNA is determined by the rate of translational initiation and elongation, polysome analysis can be used to assess the global translational level. Polysome fractionation enables direct monitoring of the efficiency of translation, but can also provide a snapshot of the mRNAs being actively recruited and translated. By treating cells with a translation elongation inhibitor, such as cycloheximide or emetine, elongating polyribosomes can be frozen on the mRNA they are translating and analyzed. The polyribosomes are separated from monosomes, as well as the individual ribosomal subunits by sucrose gradient fractionation. Sequencing the mRNAs in each fraction allows direct determination of the differential translation of individual mRNAs on a genome-wide scale. In addition to studying changes in mRNA recruitment, a polyribosome fractionation protocol can be used to isolate and characterize the translation factors and other proteins associated with mRNA on ribosomes and polysomes. The proteins associated with each fraction can be analyzed by Western blotting or by shotgun proteomics with mass spectroscopy and a translated transcriptome. The most widely used stabilizing reagent used to prevent polysomal run-off for such experiments is the eukaryotic protein synthesis inhibitor cycloheximide. Cycloheximide binds the $60 \mathrm{~S}$ subunit in the translating $80 \mathrm{~S}$ ribosome, blocking translation elongation by preventing release of deacylated tRNA from the ribosomal E site after translocation [27]. Footprinting experiments have revealed protection of a single cytidine nucleotide (C3993) in the E-site of the 60S ribosomal subunit [28].

An additional ribosome profiling technique has been developed, in which ribosome protected fragments (RPFs) are generated by RNAse I treatment and analyzed by deep-sequencing $[29,30]$. A translating ribosome encloses a $\sim 30$ nt portion of this mRNA template and protects it from nuclease digestion [31]. These ribosome-protected mRNA fragments can be used to map the positions of ribosomes allowing the determination of ribosome position at single nucleotide resolution. For example, ribosome profiling can be used for determination of ribosome density on a given mRNA molecule or the identification of elements that influence translation initiation rates such as alternative initiation sites, initiation at non-AUG codons and regulatory elements such as upstream open reading frames (uORFs). Although ribosome profiling allows direct identification of ribosome position on a given mRNA molecule, the number of ribosomes associated with a given mRNA is only indirectly estimated by normalizing frequencies of reads in ribosome-associated mRNA over those observed in randomly fragmented mRNAs (total mRNA). To define translated reading frames better, the sites of translation initiation can be revealed using the protein synthesis inhibitor harringtonine to immobilize initiating ribosomes. Harringtonine immobilizes ribosomes immediately after translation initiation begins and results in footprint accumulation at all initiation sites [29,30,32]. Polysome fractionation and ribosome profiling are complementary methods that provide information regarding the number of ribosomes associated with mRNA and position of the ribosome on mRNA, respectively. 
To begin polysome studies in A. carterae, we needed to optimize use of the translational inhibitors, cycloheximide, emetine, and harringtonine, monitoring their effectiveness by ${ }^{35} \mathrm{~S}$-methionine incorporation. Our A. carterae cultures were barely responsive to these inhibitors. In contrast, ${ }^{35} \mathrm{~S}$-methionine incorporation was severely reduced by addition of chloramphenicol, an inhibitor of bacterial protein synthesis. The lab culture had begun as an axenic culture of $A$. carterae Hulbert from Bigelow National Center for Marine Algae and Microbiota (CCMP 1314) maintained in L1 medium under sterile conditions. However, the response to cycloheximide and chloramphenicol suggested that the culture had not remained axenic although unattached bacteria were not apparent by flow cytometry and attached bacteria were not detected by DAPI staining. Strategies to develop axenic cultures of dinoflagellates usually involve a labor-intensive combination of microfiltration to remove bacteria, treatment with various antibiotic or chemical regimes, collection of phototactile cells and the generation of colonies from single cells [33]. Testing requires that axenic cultures be grown in rich medium and incubated in the dark for three to four weeks in liquid media or on plates to allow any contaminants to grow. Dinoflagellates are universally associated with bacteria in the ocean. Although the number and diversity of associated bacterial genera are variable among different dinoflagellate species (reviewed [34]), they resemble an ordered and structured community rather than a random assemblage of species recruited from the marine bacterial metacommunity likely reflecting a physiological relationship [35,36]. The bacterial group most often associated with dinoflagellates is the Alphaproteobacteria, most frequently from the Roseobacter clade and its relatives [36-38]. Gammaproteobacteria, Betaproteobacteria, and Cytophaga-Flavobacteria-Bacteroides (CFB) are the other bacterial groups reported to be associated frequently with dinoflagellate species. Within the Gammaproteobacteria, Marinobacter spp. and Alteromonas spp. appear to have an association with dinoflagellates [37,39].

Although photosynthetic, most dinoflagellates are auxotrophs for B-vitamins, requiring different combinations of three B-vitamins: vitamin B12 (cobalamin), vitamin B1 (thiamine), and vitamin B7 (biotin) [40-42]. A. carterae is listed as requiring all three B-vitamins [40]. In culture, B-vitamins are provided from the L1 medium $[43,44]$, but can also be provided by unattached or episymbiotic bacteria [45]. As examples, the growth of axenic Lingulodinium polyedron grown without B-vitamins can be sustained by Maravita spp. (from the Roseobacter clade) and Marinobacter flavimaris, both B-vitamin producers [45]. Similarly, the growth of axenic Gymnodinium catenatum is stimulated by co-culture with Roseobacter spp. and Marinobacter spp. [46].

Scanning electron microscope images of $A$. carterae, such as those reported in Aquino-Cruz and Okolodkov [47] and Murray et al. [5] show the cell surface of $A$. carterae to have small, rounded structures of less than $100 \mathrm{~nm}$ on the cell surface that provide an extensive surface area (Figure 1). This is covered by an adhesive cell-surface coat, referred to as glycocalyx or "sticky fuzz", a dynamic and complex surface matrix made up of oligosaccharides covalently bound to proteins and lipids of the plasma membrane $[48,49]$. Fluorescence and transmission electron microscopy, using various FITC-linked lectins, including concanavalin A (ConA), wheat germ agglutinin (WGA), and soybean agglutinin (SBA), highlighted the complexity of cell-surface glycan assemblages and the potential role as a perfect habitat for bacterial adherents. Low numbers of attached cells might escape detection but eventually multiply sufficiently to affect overall protein synthetic rates.

To avoid the complications of associated bacteria in our investigations of protein synthesis in A. carterae, we purchased fresh axenic cultures of A. carterae Hulbert from Bigelow National Center for Marine Algae and Microbiota (CCMP 1314) to allow us to optimize the inhibition of translation by cycloheximide and other inhibitors of eukaryotic translation, as well as to enable us to quantitate protein synthetic activity in $A$. carterae and analyze mRNA recruitment. 


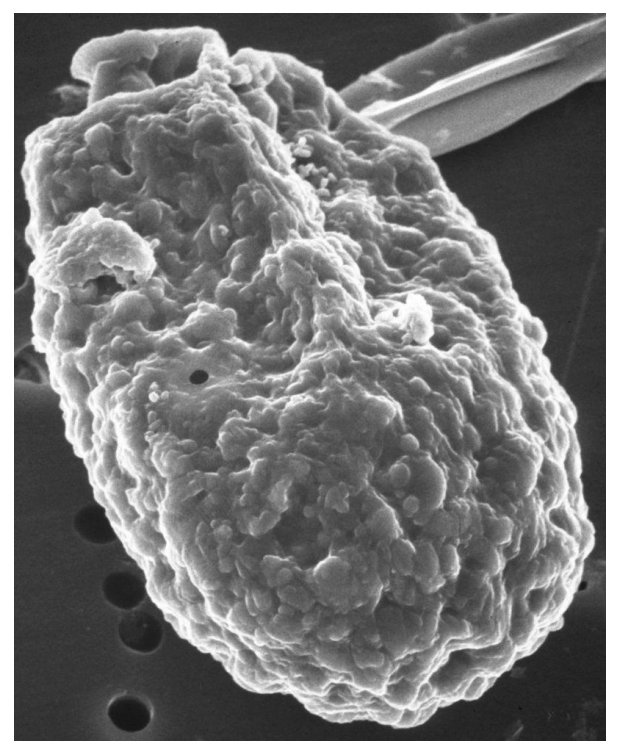

Figure 1. Scanning electron micrograph of A. carterae. Scanning electron micrograph of $A$. carterae to illustrate cell surface. From the Smithsonian Collection.

\section{Results}

\subsection{Bacterized, But Not Axenic A. carterae Show Atypical Responses to Protein Synthesis Inhibitors}

In our long-term lab cultures of $A$. carterae (CCMP 1314), incorporation of ${ }^{35}$ S-methionine into trichloracetic acid precipitable material, our measure of protein synthesis, showed little response to the eukaryotic-specific inhibitor of protein synthesis, cycloheximide, at $100 \mu \mathrm{g} / \mathrm{mL}$ (Figure 2, panel A). It seemed possible that this could reflect an unusual characteristic of dinoflagellate ribosomes. However, the bacterial (and plastid) specific protein synthesis inhibitor, chloramphenicol, reduced ${ }^{35} \mathrm{~S}$-methionine incorporation to $20 \%$ of control values. Although chloramphenicol has the potential to inhibit chloroplast protein synthesis, it seemed unlikely that this would account for $80 \%$ of measured A. carterae protein synthesis. A likelier explanation was that a significant proportion of the protein synthetic activity observed in our lab A. carterae cultures reflected the activity of an associated bacterial community. This was surprising since contaminating bacteria could not be observed. To validate such a conclusion, we obtained fresh axenic A. carterae Hulbert (CCMP 1314, Bigelow National Center for Marine Algae and Microbiota, East Boothbay, Maine) and looked again at the effects of the two protein synthesis inhibitors. The incorporation of $\left[{ }^{35} \mathrm{~S}\right]$ methionine into TCA precipitable radioactivity was corrected for the decay of ${ }^{35} \mathrm{~S}$ and calculated as cpm per $5 \times 10^{5}$ cells. The data is expressed as a percentage of the control value. The stocks of protein synthesis inhibitors are dissolved in water at $1000 \times$ the final concentration needed, so control cultures have an equivalent volume of water added. In the axenic culture, cycloheximide reduced ${ }^{35} \mathrm{~S}$-methionine incorporation to less than $15 \%$ of control values (Figure 2, panel B). In contrast, chloramphenicol gave at most a $10 \%$ reduction in ${ }^{35} \mathrm{~S}$-methionine incorporation. Overall these responses supported our conclusion that our long-term $A$. carterae cultures had become bacterized.

To determine the validity of our inference that the difference in behavior of the axenic culture reflected the absence of a bacterial community, we looked for the presence of bacteria by amplification of $16 \mathrm{~S}$ rDNA by PCR amplification using two universal primers; the bacterial 16S rDNA primer; 27F (5'-AGAGTTTGATCMTGGCTCAG-3'), and Univ1492R (5'-GGTTACC TTGTTACGACTT-3'), the numbering based on where these fall in Escherichia coli $16 \mathrm{~S}$ rDNA [50,51]. Use of these primers generates amplicons of $\sim 1.5 \mathrm{kbp}$. By this method, bacteria were not detected in the axenic culture (Figure 3, lanes 1 and 2), but were detected after maintenance of this culture without antibiotics for 4 months (Figure 3, lanes 3 and 4). 
A B C

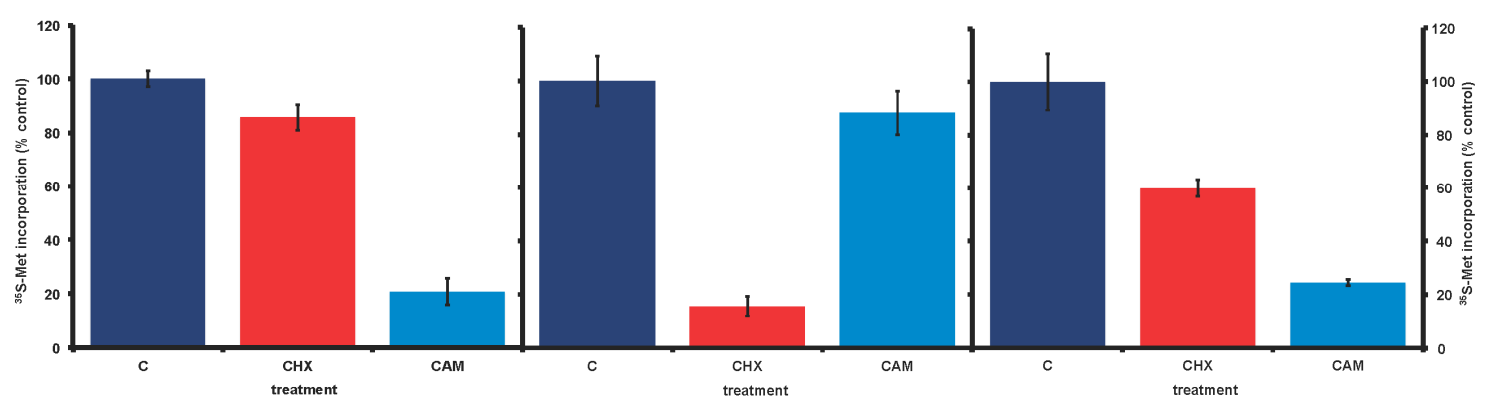

Figure 2. Effect of cycloheximide and chloramphenicol on ${ }^{35} \mathrm{~S}$-methionine incorporation in nonaxenic and axenic A. carterae. A. carterae cultures were pre-incubated with or without cycloheximide $(100 \mu \mathrm{g} / \mathrm{mL})$ or chloramphenicol $(50 \mu \mathrm{g} / \mathrm{mL})$ for $1 \mathrm{~h}$ at $20{ }^{\circ} \mathrm{C}$ prior to incubation with $\left[{ }^{35} \mathrm{~S}\right]$ methionine $\left(50 \mu \mathrm{Ci} \cdot \mathrm{mL}^{-1}\right)$ at $20^{\circ} \mathrm{C}$ for $1 \mathrm{~h}$. (A): nonaxenic A. carterae; (B): A. carterae (CCMP 1314, Bigelow National Center for Marine Algae and Microbiota); and (C): axenic A. carterae after maintenance in culture without antibiotics for four months. Without protein synthesis inhibitors (C) (dark blue); plus cycloheximide (CHX) (red); plus chloramphenicol (CAM) (light blue). The incorporation of $\left[{ }^{35} \mathrm{~S}\right]$ methionine into TCA precipitable radioactivity was corrected for decay of ${ }^{35} \mathrm{~S}$ and calculated as cpm per $5 \times 10^{5}$ cells to allow comparison between different experiments. However, incorporation of $\left[{ }^{35} \mathrm{~S}\right]$ methionine into TCA precipitable radioactivity is expressed here as a percentage of that in the control culture without antibiotics. Data are presented as the mean \pm S.D ( $n=3$ replicates).

Although this universal $16 \mathrm{~S}$ primer set is known to amplify mitochondrial and plant chloroplast rRNA genes, the divergent sequences and fragmented nature of the mitochondrial and plastid 16S rRNA genes in $A$. carterae are not amplified by these primers $[52,53]$.
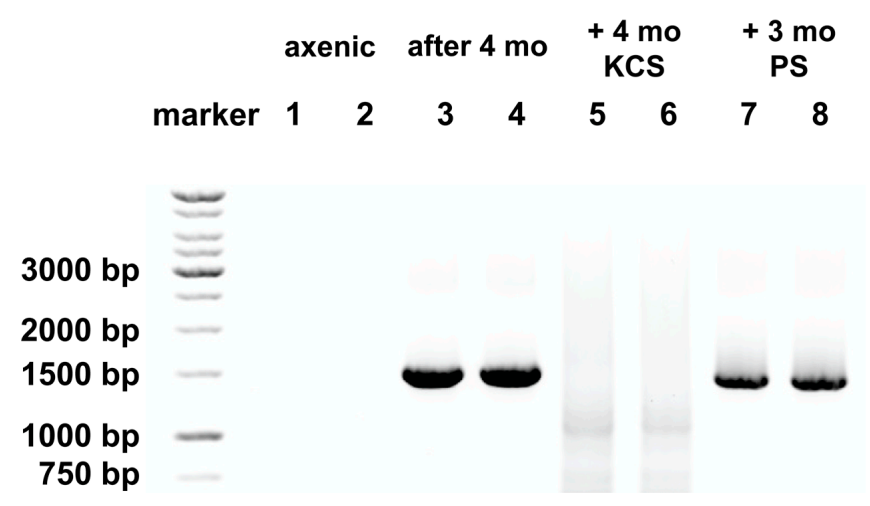

Figure 3. Bacterial rDNA reappears in axenic $A$. carterae cultures over time. The presence of bacterial $16 \mathrm{~S}$ ribosomal gene (rDNA) was determined in axenic $A$. carterae maintained in culture with and without antibiotics. DNA was isolated from axenic cultures of A. carterae Hulbert (CCMP 1314, Bigelow National Center for Marine Algae and Microbiota) and tested for bacterial contamination by amplication of DNA using two universal primers to bacterial $16 \mathrm{~S}$ ribosomal RNA gene; $27 \mathrm{~F}$ (5'-AGAGTTTGATCMTGGCTCAG-3') and Univ1492R (5'-GGTTACCTTGTTAC GACTT-3') [50,51]. Amplicons were fractionated by $1 \%$ agarose gel electrophoresis, visualized by ethidium bromide staining. Images were generated by ChemiDocTMTouch ${ }^{\mathrm{TM}}$ (Bio-Rad, Hercules, CA, USA). Lanes 1 and 2: axenic culture, Lanes 3 and 4: the same culture after 4 months in culture without antibiotics; Lanes 5 and 6: the same culture after four months without antibiotics, followed by four months with KCS; Lanes 7 and 8: the same culture after four months in culture without antibiotics followed by three months in PS. 


\subsection{Atypical Responses to Protein Synthesis Inhibitors and Bacteria Reappear with Time in Culture}

Later experiments, using the axenic culture after several weeks, showed that the responses to cycloheximide and chloramphenicol had reverted with time, such that higher incorporation of ${ }^{35} \mathrm{~S}$-methionine was observed in the presence of cycloheximide, while chloramphenicol gave a pronounced inhibition (Figure 2, panel C). These changed characteristics were reflected in the re-appearance of bacterial rDNA (Figure 3, lanes 3 and 4).

\subsection{KCS, But Not PS, Prevents Re-Emergence of Bacteria}

There are many reports of the use of antibiotics to generate axenic cultures of dinoflagellates. This may not be possible for heterotrophic dinoflagellates unless they are grown in a rich medium that replaces the nutrients their bacterial associates can provide. However, for photoautotrophic dinoflagellates, it is less of a challenge. A laboratory culture of A. carterae that had Moraxella and Pseudomonas Group IV associated with it was grown in gentamicin, chloramphenicol, and ciprofloxacin [54]. This antibiotic mix failed to totally eliminate these bacteria. Although the bacteria could not be detected $24 \mathrm{~h}$ after addition of the antibiotics, after a week, the same bacteria could be found again. Even if successful at eliminating associated bacteria, the continual presence of antibiotics might negatively affect growth and/or otherwise impact the physiological properties of the algae. Soffer et al. [55] compared 13 different antibiotic formulations on growth and presence of bacterial contaminants in liquid cultures of Symbiodinium. Certain antibiotics such as erythromycin, doxycycline, tetracyclin and chloramphenicol negatively impacted Symbiodinium growth. Other antibiotics, such as kanamycin, ampicillin, streptomycin, and G418 did not inhibit Symbiodinium growth, but individually failed to prevent bacterial contamination. A combination of penicillin and streptomycin reduced Symbiodinium growth somewhat, but could not eliminate bacterial growth. A combination of kanamycin $(50 \mu \mathrm{g} / \mathrm{mL})$, ampicillin $(100 \mu \mathrm{g} / \mathrm{mL})$, and streptomycin $(50 \mu \mathrm{g} / \mathrm{mL})$ eliminated bacterial contamination without impacting Symbiodinium growth. Similarly, Hao et al. were able to maintain axenic cultures of A. carterae with a combination of kanamycin, neomycin, and streptomycin and found that this not only prolonged the duration of exponential growth, but also increased the maximum density achieved by $25 \%[40]$.

The study by Soffer et al. using antibiotics to eliminate bacterial contamination from a dinoflagellate culture was the most comprehensive we had seen [55]. The kanamycin/ampicillin/streptomycin mix identified as the most effective by Soffer et al. has been used by others to successfully develop axenic Symbiodinium strains for introduction into a cnidarian host, Aiptasia, as a symbiont [56]. We adopted this mix, but replaced ampicillin with carbenicillin, a carboxypenicillin. Compared to ampicillin, carboxypenicillins are much more resistant to degradation by $\beta$-lactamase enzymes [57]. We compared this mix to the use of 100 units $/ \mathrm{mL}$ each of penicillin and streptomycin sulfate, antibiotics that are routinely used in the generation of axenic dinoflagellates [33]. Maintenance in an antibiotic mix of kanamycin $(50 \mu \mathrm{g} / \mathrm{mL})$, carbenicillin $(100 \mu \mathrm{g} / \mathrm{mL})$, and streptomycin sulfate $(50 \mu \mathrm{g} / \mathrm{mL})(\mathrm{KCS})$ prevented the reappearance of bacterial rDNA in our cultures even after four months (Figure 3, lanes 5 and 6). However, penicillin and streptomycin (PS) both at $100 \mu \mathrm{g} / \mathrm{mL}$, did not, with clearly apparent bacterial rDNA signatures (Figure 3, lanes 7 and 8). A faint band can be seen in DNA from cultures maintained in KCS at $\sim 1100$ bp and a more diffuse smear at $\sim 700$ bp (Figure 3, lanes 5 and 6). This reflects mispriming of the bacterial primer 27F when bacterial rDNA is not present, and under the amplification conditions used. To ensure amplification of all bacterial rRNA, a low stringency annealing temperature of $46^{\circ} \mathrm{C}$ was used with high cycle number ( 40 cycles). This has the potential to generate low levels of misprimed amplicons when authentic targets are not available. It has previously been reported that use of this primer set at low stringency can give rise to cross-kingdom amplification of rRNA genes, as is the case for the Pacific scleractinian coral Pocillopora damicornis [58]. Upon inspection of the rRNA gene sequence from A. carterae, accession \#AF274251.1, areas of (poor) sequence homology with the bacterial primer $27 \mathrm{~F}$ at $172-190,655-673,718-737$, and the universal primer 1492R. At low stringency, such as that used here, and without authentic targets to compete, 
the primer combinations could produce amplicons from A. carterae rDNA of approximately $1584 \mathrm{bp}$ (which would not be distinguished from the bacterial rDNA amplicons), $1101 \mathrm{bp}$, as well as a smeary band between 707 and $717 \mathrm{bp}$. A faint band at $\sim 1100$ bp and smeary band of $\sim 700$ bp can be seen Figure 3 , lanes 5 and 6 corresponding to this.

\subsection{KCS, But Not PS, Prevents Atypical Responses to Protein Synthesis Inhibitors, But Does Not Impact the Growth Rate of A. carterae}

Consistent with the presence or absence of bacteria, incorporation of ${ }^{35} \mathrm{~S}$-methionine in A. carterae maintained in KCS shows the expected eukaryotic responses to cycloheximide and chloramphenicol. Cycloheximide reduced ${ }^{35} \mathrm{~S}$-methionine incorporation to less than $15 \%$ of control values, whereas chloramphenicol gave approximately a $10 \%$ reduction in ${ }^{35} \mathrm{~S}$-methionine incorporation (Figure 4 , panel A). In contrast, in A. carterae maintained in PS for three months, cycloheximide only reduced ${ }^{35} \mathrm{~S}$-methionine incorporation to $\sim 60 \%$ of control, whereas, chloramphenicol reduced it to $\sim 45 \%$ suggesting that more than half the protein synthetic activity could be attributed to the bacterial community (Figure 4, panel B).

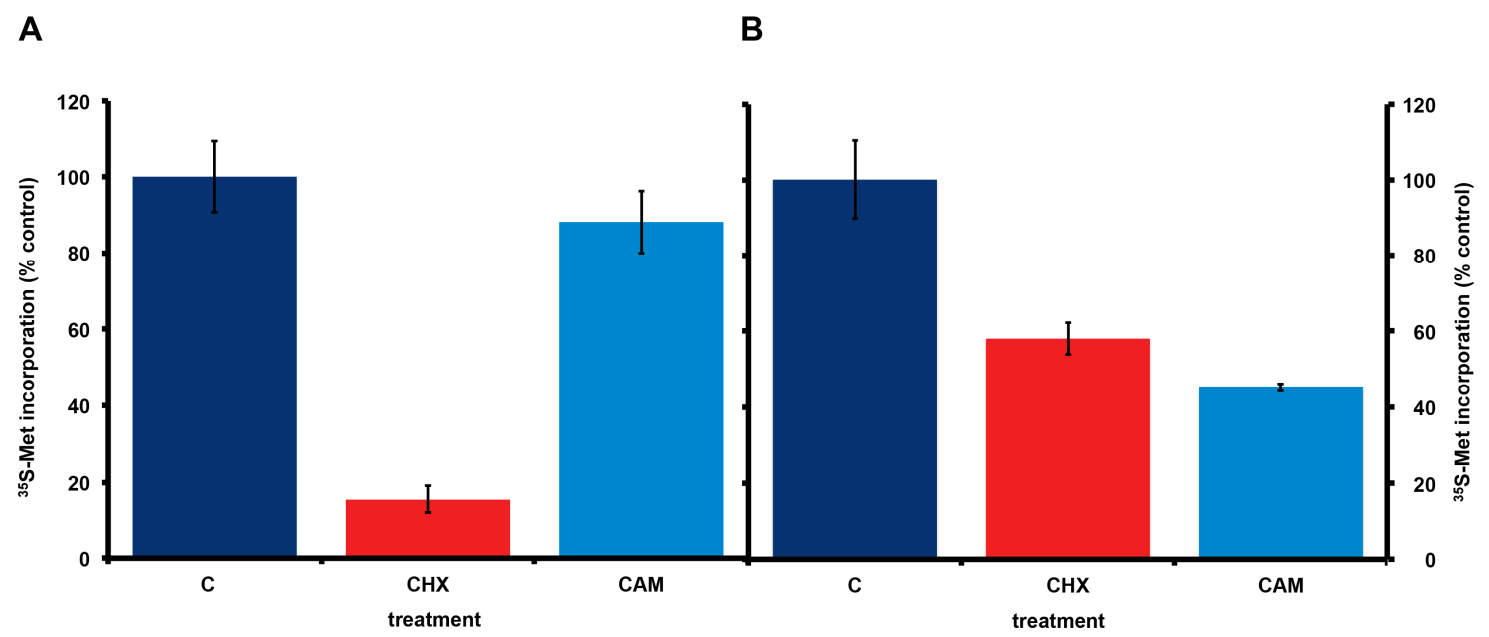

Figure 4. Effect of cycloheximide and chloramphenicol on ${ }^{35} \mathrm{~S}$-methionine incorporation in $A$. carterae axenic cultures maintained in different antibiotics. A. carterae were pre-incubated with or without cycloheximide $(100 \mu \mathrm{g} / \mathrm{mL})$ or chloramphenicol $(50 \mu \mathrm{g} / \mathrm{mL})$ for $1 \mathrm{~h}$ at $20{ }^{\circ} \mathrm{C}$ prior to incubation with $\left[{ }^{35} \mathrm{~S}\right]$ methionine $\left(50 \mu \mathrm{Ci} \cdot \mathrm{mL}^{-1}\right)$ at $20{ }^{\circ} \mathrm{C}$ for $1 \mathrm{~h}$. (A): cells maintained in $\mathrm{KCS}$ for 4 months; (B): cells maintained in PS for 3 months. Incorporation of $\left[{ }^{35} \mathrm{~S}\right]$ methionine into TCA precipitable radioactivity is expressed as a percentage of that in control cultures without protein synthesis inhibitors. The incorporation of $\left[{ }^{35} \mathrm{~S}\right]$ methionine into TCA precipitable radioactivity was corrected for decay of ${ }^{35} \mathrm{~S}$ and calculated as cpm per $5 \times 10^{5}$ cells. Data are presented as the mean $\pm \mathrm{S} . \mathrm{D}$ ( $n=3$ replicates). Control (dark blue); plus cycloheximide (CHX) (red); plus chloramphenicol (CAM) (light blue).

Since we have expressed the incorporation of ${ }^{35} \mathrm{~S}$-methionine as a percentage of that in control cultures for clarity, any impact of long term culture in antibiotics on ${ }^{35} \mathrm{~S}$-methionine incorporation is not apparent. However, from the data above and other experiments, the ${ }^{35} \mathrm{~S}$-methionine incorporation for cells in KCS is $10,081 \mathrm{cpm} / 5 \times 10^{5}$ cells, adjusted for ${ }^{35} \mathrm{~S}$ half-life. The corresponding figure is $9867 \mathrm{cpm} / 5 \times 10^{5}$ cells, adjusted for ${ }^{35} \mathrm{~S}$ half-life in cells maintained in PS for 3months. Both are $15-20 \%$ higher than in cells maintained without antibiotic $\left(8064 \mathrm{cpm} / 5 \times 10^{5}\right.$ cells, adjusted for ${ }^{35} \mathrm{~S}$ half-life). Considering that $80 \%$ of ${ }^{35} \mathrm{~S}$-methionine incorporation in the bacterized cultures reflects the bacterial community, this suggests that protein synthetic activity in A. carterae maintained in KCS, is approximately five times higher than in the bacterized cells. It was observed that inclusion of either antibiotic mix gives an initial drop in ${ }^{35} \mathrm{~S}$-methionine incorporation presumably as the bacterial count falls (data not shown). However, once the bacterial community is removed, ${ }^{35} \mathrm{~S}$-methionine 
incorporation rises presumably due to the lack of competition from the bacterial community. However, still concerned over whether the antibiotics would impact $A$. carterae growth, we also looked at the effects of the antibiotics on growth. Reverted axenic cultures were exchanged into medium supplemented with or without KCS or PS for three days prior to the start of the growth curves which were begun at a starting density of $\sim 1 \times 10^{5} / \mathrm{mL}$. Cultures growing with KCS grew at the same rate as control cultures, but the growth phase persisted longer and achieved higher final densities (Figure 5, panel A). The growth of cultures in PS began to slow down sooner than control cultures and achieved lower final densities (Figure 5, panel A).
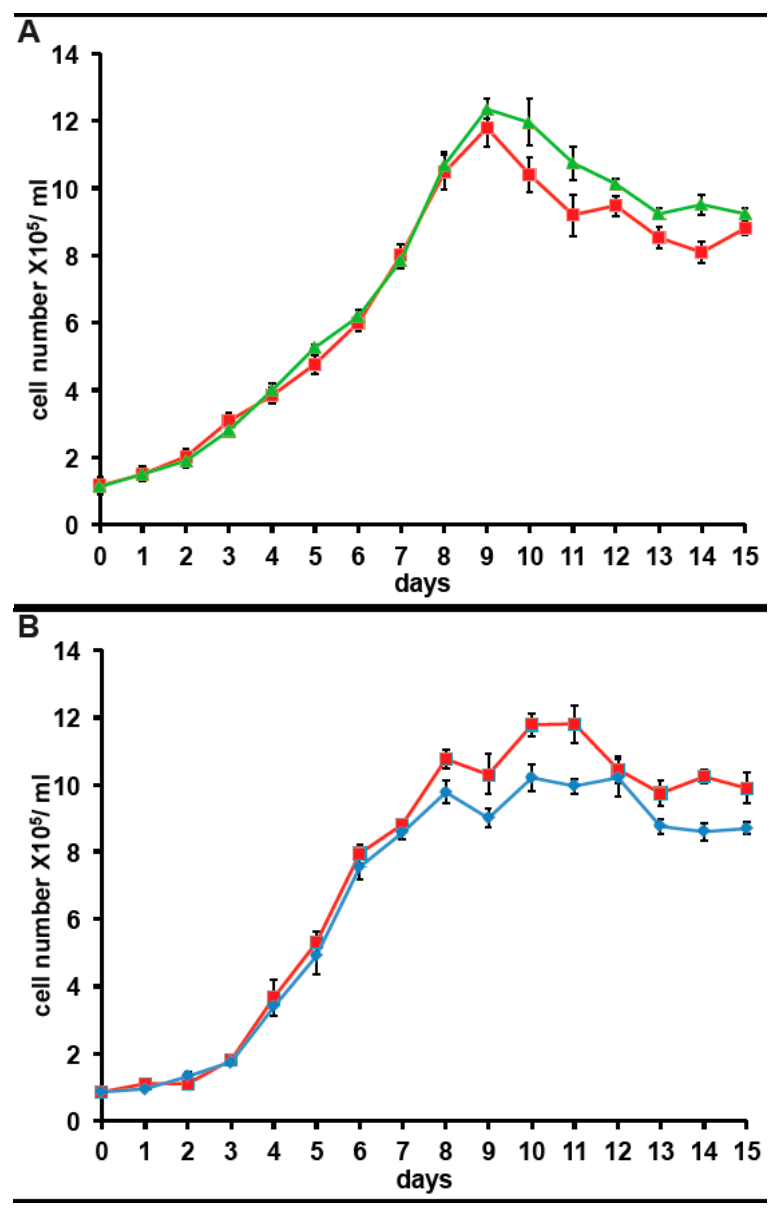

Figure 5. Effect of antibiotics on growth of A. carterae. Axenic A. carterae maintained without antibiotics for 5 months were exchanged into medium supplemented with or without KCS or PS for 3 days prior to start of growth curve. Growth curves were begun at a starting density of $\sim 1 \times 10^{5} / \mathrm{mL}$. Cell counts were measured daily. Data are presented as the mean \pm S.D $(n=3$ replicates). Without antibiotics (red square); plus KCS (green triangles); plus PS (blue diamond). (A): comparison of growth with/without KCS; (B): comparison of growth with/without PS.

\subsection{Effect of Other Protein Synthesis Inhibitors on ${ }^{35}$ S-Methionine Incorporation in Axenic A. carterae Maintained in KCS}

A. carterae maintained in KCS has remained free of bacteria for several months, as measured by the response to cycloheximide and chloramphenicol and lack of PCR-amplifiable $16 \mathrm{~S}$ rDNA. Over this time, the growth rate, ${ }^{35} \mathrm{~S}$-methionine incorporation and final cell densities of the culture has remained consistent and has been used to look at the effects of other agents that inhibit protein synthesis in eukaryotes. This culture has remained consistent in its response to cycloheximide (CHX) which reduces ${ }^{35} \mathrm{~S}$-methionine incorporation to less than $15 \%$ of control values, as well as to chloramphenicol (CAM) 
which causes less than a 10\% reduction (Figure 6). Other inhibitors of eukaryotic protein synthesis, emetine (Em) and harringtonine (Har) also inhibit ${ }^{35} \mathrm{~S}$-methionine incorporation. Cycloheximide, emetine and harringtonine will be used to dissect the regulation of mRNA recruitment in A. carterae. Sodium arsenite (AsO), used to mimic oxidative stress, also inhibits ${ }^{35} \mathrm{~S}$-methionine incorporation. In contrast, thapsigargin (TPG), a non-competitive inhibitor of the endoplasmic reticulum $\mathrm{Ca}^{2+} \mathrm{ATPase}$ does not. TPG inhibits protein synthesis in metazoans as a consequence of metabolic stress through phosphorylation of the translation initiation factor eIF2 [59].

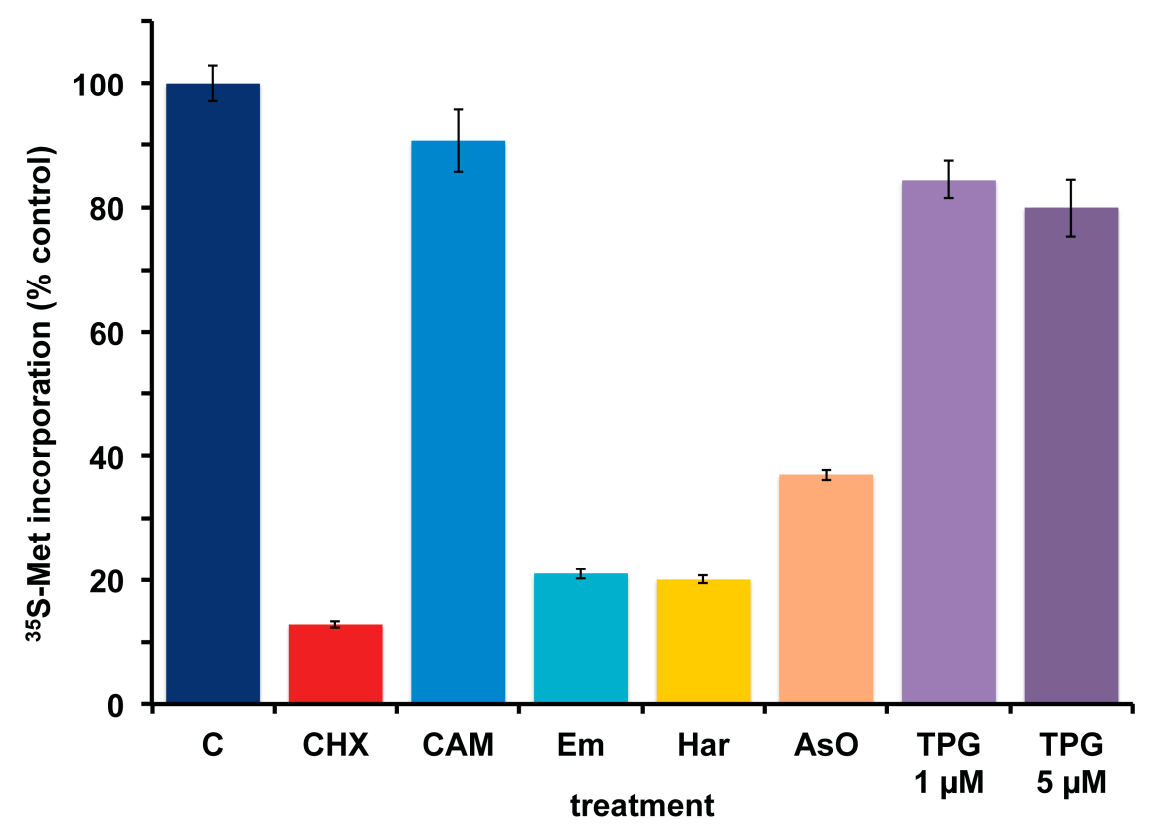

Figure 6. Effect of protein synthesis inhibitors on ${ }^{35} \mathrm{~S}$-methionine incorporation in axenic $A$. carterae maintained in KCS. A. carterae were pre-incubated for $1 \mathrm{~h}$ at $20^{\circ} \mathrm{C}$ with or without a range of protein synthesis inhibitors: cycloheximide, $100 \mu \mathrm{g} / \mathrm{mL}$; chloramphenicol, $50 \mu \mathrm{g} / \mathrm{mL}$; emetine, $360 \mu \mathrm{M}$; harringtonine, $37.6 \mu \mathrm{M}$; sodium arsenite, $400 \mu \mathrm{M}$; thapsigargin, $1 \mu \mathrm{M}$ and $5 \mu \mathrm{M}$, prior to incubation with $\left[{ }^{35} \mathrm{~S}\right]$ methionine $\left(50 \mu \mathrm{Ci} \cdot \mathrm{mL}^{-1}\right)$ at $20{ }^{\circ} \mathrm{C}$ for $1 \mathrm{~h}$. Incorporation of $\left[{ }^{35} \mathrm{~S}\right]$ methionine into TCA precipitable radioactivity is expressed as a percentage of that in control culture without antibiotics. The incorporation of $\left[{ }^{35} \mathrm{~S}\right]$ methionine into TCA precipitable radioactivity was corrected for the decay of ${ }^{35} \mathrm{~S}$ and calculated as cpm per $5 \times 10^{5}$ cells. Data are presented as the mean $\pm \operatorname{S.D}(n=3$ replicates). Without antibiotics (dark blue); plus cycloheximide (CHX) (red); plus chloramphenicol (CAM) (light blue); plus emetine (Em) (teal blue); plus harringtonine (Har) (yellow); plus sodium arsenite (AsO) (orange); plus thapsigargin (TPG) (purple).

\section{Discussion}

In order to study translation regulation of gene expression in A. carterae, we needed to grow cultures without the associated bacterial community. Strategies to develop axenic cultures of dinoflagellates usually involve a labor-intensive combination of microfiltration to remove bacteria, treatment with chemicals or various antibiotic regimes, collection of phototactile cells and the generation of colonies from single cells [33]. We were able to purchase axenic cultures of $A$. carterae Hulbert from but found that over a few months a bacterial community was re-established. We consider that the most likely source of contamination comes from low levels of bacteria that remain closely associated with the surface of $A$. carterae. Drawing on the work of others, we found that the combination of kanamycin, carbenicillin, and streptomycin, but not the combination of penicillin and streptomycin, allow A. carterae to grow without PCR-detectable bacteria over several months. Axenic cultures will allow us to measure protein synthesis rates under different conditions and over the diel cycle, evaluate conditions that stimulate or inhibit protein synthesis and study changes in 
mRNA recruitment. Other workers in the field looking at translational regulation in dinoflagellates have included prokaryotic inhibitors of protein synthesis like chloramphenicol in the culture medium at the time of their experiment to inhibit incorporation of methionine by the bacterial community present in the cultures [60]. Our data have indicated that this is not an ideal strategy since the dinoflagellates are functioning under sub-optimal nutrient conditions for protein synthesis. It is not known what the long-term effect of antibiotic supplementation are on chloroplast protein synthesis may be. Our KCS-maintained cultures show no signs of deterioration after six months. There is no information in the literature on what fraction of total protein synthesis takes place in the dinoflagellate chloroplast, although it is known that many genes typically located within the chloroplast genome have been transferred to the nuclear genome [61,62] and the rRNA genes are fragmented [52,53]. However, when both cycloheximide and chloramphenicol are included during ${ }^{35} \mathrm{~S}$-methionine incorporation, little further reduction is observed over cycloheximide alone, suggesting that chloroplast protein synthesis may be very low.

In addition to providing the axenic cultures we need for our research, this study has demonstrated that a simple and fast appraisal of the presence of a bacterial community in dinoflagellate cultures can be made by comparing responses to the protein synthesis inhibitors cycloheximide and chloramphenicol rather than depending on lengthier culture-based assessments. The labor-intensive generation of axenic dinoflagellate cultures render it important to test for bacterial contamination on a regular basis. This can be done by epifluorescence microscopy or by PCR amplification of 16S rDNA in those dinoflagellate species that have chloroplast $16 \mathrm{~S}$ rRNA genes amplified by $16 \mathrm{~S}$ universal primers. A routine and expedient assessment of the response to eukaryotic and prokaryotic inhibitors of protein synthesis could provide a desirable alternative that could be easier for small labs to implement. We plan to follow up these findings by making a comprehensive assessment of the microbiota by combining mass-amplification of bacterial 16S rRNA with universal primers and high-throughput sequencing using MiSeq. Identification of the members of the bacterial community may enable us to choose more effective antibacterial strategies as well as optimize A. carterae culture media.

\section{Materials and Methods}

\subsection{Antibiotics and Protein Synthesis Inhibitors}

Chloramphenicol (C0378) and emetine (E2375) were from Sigma (St. Louis, MO, USA). Cycloheximide (94271) was from Amresco (Solon, OH, USA). Sodium arsenite (S-2251) was from Fisher Scientific (Fair lawn, NJ, USA). Thapsigargin (586005) Calbiochem (San Diego, CA, USA). Harringtonine (H0169) was from LKT Labs (St. Paul, MN, USA).

\subsection{A. carterae Cell Culture}

A. carterae Hulbert [43] was obtained from the National Center for Marine Algae and Microbiota (CCMP1314, Bigelow National Center for Marine Algae and Microbiota), grown under sterile conditions in filtered L1 medium in 35 ppt seawater containing L1 trace element solution and $\mathrm{f} / 2$ vitamin solution [44]. Cultures were grown at $20{ }^{\circ} \mathrm{C}$ with $14: 10$ light: dark cycle with a photon flux density of $35 \mu \mathrm{mol} \cdot \mathrm{m}^{-2} \cdot \mathrm{s}^{-1}$. Cultures were supplemented with or without kanamycin $(50 \mu \mathrm{g} / \mathrm{mL}) /$ carbenicillin $(100 \mu \mathrm{g} / \mathrm{mL}) /$ streptomycin $(50 \mu \mathrm{g} / \mathrm{mL})(\mathrm{KCS})$, or 100 units $/ \mathrm{mL}$ of penicillin and streptomycin sulfate (PS). Cultures were counted daily to monitor growth with cells collected at mid-day. Cell density was maintained at $4-6 \times 10^{5} \mathrm{~mL}^{-1}$ for measurements of ${ }^{35} \mathrm{~S}$-methionine incorporation. Cells were also collected at mid-day for DNA extraction and PCR amplification of bacterial rDNA.

\subsection{Determination of Cell Number}

Cells were removed aseptically for cell number determination and harvested by centrifugation at $1000 \times g$. The recovered cells were resuspended and mixed with a drop of iodine solution 
(Lugol's solution). After suitable dilution, using triplicate samples, cells were counted by hemocytometer at $100 \times$ magnification, in quadrants $1-4$. The average cell count from the four quadrants and the average calculated. Cell number was calculated by multiplying by $10^{4}$, the dilution factor, and the total volume $(\mathrm{mL})$. Cell numbers were determined in triplicate.

\subsection{Detection of Bacteria by PCR Amplification}

Cells were harvested using centrifugation at $1000 \times g$ for $10 \mathrm{~min}$, followed by two washes with cold L1. DNA was prepared from 0.8-1.4 $\times 10^{6}$ cells using the MP FastSPIN DNA extraction kit (MP Biochemicals, Solon, OH, USA) following the manufacturer's protocol. DNA was analyzed spectrally using Nanodrop ND-1000 spectrophotometry (Agilent, Santa Clara, CA, USA) and amplified using two universal primers to bacterial $16 \mathrm{~S}$ ribosomal RNA gene; 27F (5'-AGAGTTTGATCMTGGCTCAG-3') and Univ1492R (5'-GGTTACCTTGTTACGACTT-3') [50,51]. Amplification of DNA fragments of the predicted size was confirmed by end-point PCR using $10 \mathrm{ng}$ DNA. Thermal cycling parameters were as follow: initial denaturation at $95^{\circ} \mathrm{C}$ for $5 \mathrm{~min}$, followed by 39 cycles of denaturation at $92^{\circ} \mathrm{C}$ for $30 \mathrm{~s}$, annealing at $46{ }^{\circ} \mathrm{C}$ for $2 \mathrm{~min}$, and extension at $72{ }^{\circ} \mathrm{C}$ for $90 \mathrm{~s}$. Extension at $72{ }^{\circ} \mathrm{C}$ for $7 \mathrm{~min}$ followed the last cycle. Amplicons were fractionated by $1 \%$ agarose gel electrophoresis, visualized by ethidium bromide staining and an image generated by ChemiDoc ${ }^{\mathrm{TM}}$ Touch imaging system (Bio-Rad, Hercules, CA, USA).

\section{5. ${ }^{35}$ S-Methionine Incorporation}

For $\left[{ }^{35} \mathrm{~S}\right.$ ] methionine labeling experiments, cells were used at $4 \sim 6 \times 10^{5} \mathrm{~mL}^{-1}$. The cultures were incubated with $\left.{ }^{35} \mathrm{~S}\right]$ methionine $\left(50 \mu \mathrm{Ci} \cdot \mathrm{mL}^{-1}\right)$ (PerkinElmer, Boston, MA, USA) for $1 \mathrm{~h}$. After labeling, cells were recovered by centrifugation at $1000 \times g$ followed by two washes with cold L1 containing $2 \mathrm{mM}$ methionine. The cell pellet was resuspended in $1 \mathrm{~mL} \mathrm{10 \%} \mathrm{trichloroacetic} \mathrm{acid} \mathrm{(TCA)} \mathrm{containing}$ $2 \mathrm{mM}$ methionine and kept on ice for $10 \mathrm{~min}$. The samples were incubated at $90{ }^{\circ} \mathrm{C}$ for $15 \mathrm{~min}$ to deacylate Met-tRNAs. After cooling on ice, the TCA precipitate was filtered through GFC filter paper (Whatman, GE health care Life Science, Little Chalfont, Buckinghamshire, UK), and rinsed with 5\% TCA containing $2 \mathrm{mM}$ methionine. Radioactivity was monitored on dried filters by scintillation counting (Beckman, LS6500, Indianapolis, IN, USA). The incorporation of $\left[{ }^{35} \mathrm{~S}\right]$ methionine into TCA precipitable radioactivity was corrected for decay of ${ }^{35} \mathrm{~S}$ and calculated as cpm per $5 \times 10^{5}$ cells.

\subsection{Effect of Inhibitors of Protein Synthesis on ${ }^{35}$ S-Methionine Incorporation}

Cultures $(n=3)$ at $4 \sim 6 \times 10^{5} \mathrm{~mL}^{-1}$ were pre-incubated for $1 \mathrm{~h}$ with or without protein synthesis inhibitors: cycloheximide (CHX), $100 \mu \mathrm{g} / \mathrm{mL}$; chloramphenicol (CAM), $50 \mu \mathrm{g} / \mathrm{mL}$; emetine (Em), $360 \mu \mathrm{M}$; harringtonine (Har), $37.6 \mu \mathrm{M}$; sodium arsenite (AsO), $400 \mu \mathrm{M}$; thapsigargin (TPG), $1 \mu \mathrm{M}$ and $5 \mu \mathrm{M}$. Cells were incubated with $\left.{ }^{35} \mathrm{~S}\right]$ methionine $\left(50 \mu \mathrm{Ci} \cdot \mathrm{mL}^{-1}\right)$ for $1 \mathrm{~h}$ and processed as described in Section 4.4. Incorporation of $\left[{ }^{35} \mathrm{~S}\right]$ methionine into TCA precipitable radioactivity was corrected for ${ }^{35} \mathrm{~S}$ half-life and expressed per $5 \times 10^{5}$ cells. Data are presented as the percentage of control showing the mean \pm S.D ( $n=3$ replicates). Control incubations include an equal volume of the vehicle used for solubilizing. Cycloheximide, chloramphenicol, and sodium arsenite were solubilized in water. Emetine, thapsigargin, and harringtonine were solubilized in dimethyl sulfoxide (DMSO). These were all used at 1/1000 and there was no difference between the water and DMSO.

Acknowledgments: This work was supported by funding from Oceans and Human Health NIHR01ES021949-01/NSF OCE1313888 to R.J. and A.R.P. We thank Tsetso Bachvaroff and Kathleen Gillespie for interesting discussions and feedback on the manuscript. This is contribution \#5361 from the University of Maryland Center for Environmental Science (UMCES) and \#17-207 for the Institute of Marine and Environmental Technology (IMET).

Author Contributions: R.J. and A.R.P. conceived the experiments. R.J. and C.-L.L. designed the experiments. C.-L.L. performed the experiments. R.J. and C.-L.L. wrote the paper with input from A.R.P.

Conflicts of Interest: The authors declare no conflict of interest. 


\section{References}

1. Zhang, H.; Bhattacharya, D.; Lin, S. A three-gene dinoflagellate phylogeny suggests monophyly of prorocentrales and a basal position for Amphidinium and Heterocapsa. J. Mol. Evol. 2007, 65, 463-474. [CrossRef] [PubMed]

2. Bachvaroff, T.R.; Handy, S.M.; Place, A.R.; Delwiche, C.F. Alveolate phylogeny inferred using concatenated ribosomal proteins. J. Eukaryot. Microbiol. 2011, 58, 223-233. [CrossRef] [PubMed]

3. Bachvaroff, T.R.; Gornik, S.G.; Concepcion, G.T.; Waller, R.F.; Mendez, G.S.; Lippmeier, J.C.; Delwiche, C.F. Dinoflagellate phylogeny revisited: Using ribosomal proteins to resolve deep branching dinoflagellate clades. Mol. Phylogenet. Evol. 2014, 70, 314-322. [CrossRef] [PubMed]

4. Janouškovec, J.; Gavelis, G.S.; Burki, F.; Dinh, D.; Bachvaroff, T.R.; Gornik, S.G.; Bright, K.J.; Imanian, B.; Strom, S.L.; Delwiche, C.F.; et al. Major transitions in dinoflagellate evolution unveiled by phylotranscriptomics. Proc. Natl. Acad. Sci. USA 2017, 114, E171-E180. [CrossRef] [PubMed]

5. Murray, S.A.; Garby, T.; Hoppenrath, M.; Neilan, B.A. Genetic diversity, morphological uniformity and polyketide production in dinoflagellates (Amphidinium, Dinoflagellata). PLoS ONE 2012, 7, e38253. [CrossRef] [PubMed]

6. LaJeunesse, T.C.; Lambert, G.; Andersen, R.A.; Coffroth, M.A.; Galbraith, D.W. Symbiodinium (pyrrhophyta) genome (DNA content) are smallest among dinoflagelates. J. Phycol. 2005, 41, 880-886. [CrossRef]

7. Fuentes-Grünewald, C.; Bayliss, C.; Fonlut, F.; Chapuli, E. Long-term dinoflagellate culture performance in a commercial photobioreactor: Amphidinium carterae case. Bioresour. Technol. 2016, 218, 533-540. [CrossRef] [PubMed]

8. Gallardo-Rodríguez, J.; Sánchez-Mirón, A.; García-Camacho, F.; López-Rosales, L.; Chisti, Y.; Molina-Grima, E. Bioactives from microalgal dinoflagellates. Biotechnol. Adv. 2012, 30, 1673-1684. [CrossRef] [PubMed]

9. Nuzzo, G.; Cutignano, A.; Sardo, A.; Fontana, A. Antifungal amphidinol 18 and its 7-sulfate derivative from the marine dinoflagellate Amphidinium carterae. J. Nat. Prod. 2014, 77, 1524-1527. [CrossRef] [PubMed]

10. Moustafa, A.; Evans, A.N.; Kulis, D.M.; Hackett, J.D.; Erdner, D.L.; Anderson, D.M.; Bhattacharya, D. Transcriptome profiling of a toxic dinoflagellate reveals a gene-rich protist and a potential impact on gene expression due to bacterial presence. PLoS ONE 2010, 5, e9688. [CrossRef] [PubMed]

11. Morey, J.S.; Van Dolah, F.M. Global Analysis of mRNA Half-Lives and de novo transcription in a dinoflagellate, Karenia brevis. PLoS ONE 2013, 8, e66347. [CrossRef] [PubMed]

12. Roy, S.; Morse, D. Transcription and maturation of mRNA in dinoflagellates. Microorganisms 2013, 1, 71-99. [CrossRef] [PubMed]

13. Roy, S.; Beauchemin, M.; Dagenais-Bellefeuille, S.; Letourneau, L.; Cappadocia, M.; Morse, D. The Lingulodinium circadian system lacks rhythmic changes in transcript abundance. BMC Biol. 2014, 12, 107. [CrossRef] [PubMed]

14. Milos, P.; Morse, D.; Hastings, J.W. Circadian control over synthesis of many Gonyaulax proteins is at a translational level. Naturwissenschaften 1990, 77, 87-89. [CrossRef] [PubMed]

15. Miller-Morey, J.S.; Van Dolah, F.M. Differential responses of stress proteins, antioxidant enzymes, and photosynthetic efficiency to physiological stresses in the Florida red tide dinoflagellate, Karenia brevis. Comp. Biochem. Physiol. C Toxicol. Pharmacol. 2004, 138, 493-505. [CrossRef] [PubMed]

16. Akimoto, H.; Wu, C.; Kinumi, T.; Ohmiya, Y. Biological rhythmicity in expressed proteins of the marine dinoflagellate Lingulodinium polyedrum demonstrated by chronological proteomics. Biochem. Biophys. Res. Commun. 2004, 315, 306-312. [CrossRef] [PubMed]

17. Akimoto, H.; Kinumi, T.; Ohmiya, Y. Circadian rhythm of a TCA cycle enzyme is apparently regulated at the translational level in the dinoflagellate Lingulodinium polyedrum. J. Biol. Rhythms 2005, 20, 479-489. [CrossRef] [PubMed]

18. Lee, F.W.; Morse, D.; Lo, S.C. Identification of two plastid proteins in the dinoflagellate Alexandrium affine that are substantially down-regulated by nitrogen-depletion. J. Proteome Res. 2009, 8, 5080-5092. [CrossRef] [PubMed]

19. Liu, B.; Lo, S.C.; Matton, D.P.; Lang, B.F.; Morse, D. Daily changes in the phosphoproteome of the dinoflagellate Lingulodinium. Protist 2012, 163, 746-754. [CrossRef] [PubMed] 
20. Lidie, K.; Jagus, R.; Place, A.R. Identification in dinoflagellates of two eukaryotic translation initiation factor $4 \mathrm{E}$ homologues. In Proceedings of the 13th International Conference on Harmful Algae, Hong Kong, China, 3-7 November 2008; pp. 103-107.

21. Jones, G.D. Discovery, Phylogenetic Analysis and Characterization of eIF4E Family Members from Amphidinium carterae. Ph.D. Thesis, University of Baltimore Maryland, Baltimore, MD, USA, 2016.

22. Jones, G.D.; Williams, E.P.; Place, A.R.; Jagus, R.; Bachvaroff, T.R. The alveolate translation initiation factor $4 \mathrm{E}$ family reveals a custom toolkit for translational control in core dinoflagellates. BMC Evol. Biol. 2015, 15, 14. [CrossRef] [PubMed]

23. Jones, G.D.; Williams, E.P.; Place, A.R.; Bachvaroff, T.R.; Jagus, R. New tools in the Karlodinium veneficum translation initiation toolbox. In Proceedings of the 16th International Conference on Harmful Algae, Wellington, New Zealand, 27-31 October 2014; MacKenzie, A.L., Ed.; Cawthron Institute: Nelson, New Zealand, 2014; pp. 237-240.

24. Lidie, K.B.; van Dolah, F.M. Spliced leader RNA-mediated trans-splicing in a dinoflagellate, Karenia brevis. J. Eukaryot. Microbiol. 2007, 54, 427-435. [CrossRef] [PubMed]

25. Zhang, H.; Hou, Y.; Miranda, L.; Campbell, D.A.; Sturm, N.R.; Gaasterland, T.; Lin, S. Spliced leader RNA trans-splicing in dinoflagellates. Proc. Natl. Acad. Sci. USA 2007, 104, 4618-4623. [CrossRef] [PubMed]

26. Mašek, T.; Valášek, L.; Pospíšek, M. Polysome analysis and RNA purification from sucrose gradients. Methods Mol. Biol. 2011, 703, 293-309. [PubMed]

27. Pestova, T.V.; Hellen, C.U. Translation elongation after assembly of ribosomes on the Cricket paralysis virus internal ribosomal entry site without initiation factors or initiator tRNA. Genes Dev. 2003, 17, 181-186. [CrossRef] [PubMed]

28. Schneider-Poetsch, T.; Ju, J.; Eyler, D.E.; Dang, Y.; Bhat, S.; Merrick, W.C.; Green, R.; Shen, B.; Liu, J.O. Inhibition of eukaryotic translation elongation by cycloheximide and lactimidomycin. Nat. Chem. Biol. 2010, 6, 209-217. [CrossRef] [PubMed]

29. Ingolia, N.T.; Brar, G.A.; Rouskin, S.; McGeachy, A.M.; Weissman, J.S. The ribosome profiling strategy for monitoring translation in vivo by deep sequencing of ribosome-protected mRNA fragments. Nat. Protoc. 2012, 7, 1534-1550. [CrossRef] [PubMed]

30. Ingolia, N.T.; Brar, G.A.; Rouskin, S.; McGeachy, A.M.; Weissman, J.S. Genome-wide annotation and quantitation of translation by ribosome profiling. Curr. Protoc. Mol. Biol. 2013. [CrossRef]

31. Wolin, S.L.; Walter, P. Ribosome pausing and stacking during translation of a eukaryotic mRNA. EMBO J. 1988, 7, 3559-3569. [PubMed]

32. Huang, M.T. Harringtonine, an inhibitor of initiation of protein biosynthesis. Mol. Pharmacol. 1975, 11, 511-519. [PubMed]

33. Guillard, R. Algal Culturing Techniques; Academic Press: San Diego, CA, USA, 2005; pp. 117-132.

34. Kodama, M.; Doucette, G.; Green, D. Ecology of Harmful Algae; Springer: Berlin, Germany, 2006; pp. $243-255$.

35. Curtis, T.P.; Sloan, W.T. Prokaryotic diversity and its limits: Microbial community structure in nature and implications for microbial ecology. Curr. Opin. Microbiol. 2004, 7, 221-226. [CrossRef] [PubMed]

36. Green, D.H.; Llewellyn, L.E.; Negri, A.P.; Blackburn, S.I.; Bolch, C.J. Phylogenetic and functional diversity of the cultivable bacterial community associated with the paralytic shellfish poisoning dinoflagellate Gymnodinium catenatum. FEMS Microbiol. Ecol. 2004, 47, 345-357. [CrossRef]

37. Hold, G.; Smith, E.; Raape, M.; Maas, E.; Moore, E.; Stroempl, C.; Stephen, J.; Prosser, J.; Birkbeck, T.; Gallacher, S. Characterization of bacterial communities associated with toxic and non-toxic dinoflagellates. FEMS Microbiol. Ecol. 2001, 37, 161-173. [CrossRef]

38. Allgaier, M.; Uphoff, H.; Felske, A.; Wagner-Dobler, I. Aerobic anoxygenic photosynthesis in Roseobacter clade bacteria from diverse marine habitats. Appl. Environ. Microbiol. 2003, 69, 5051-5059. [CrossRef] [PubMed]

39. Ferrier, M.; Martin, J.L.; Rooney-Varga, J.N. Stimulation of Alexandrium fundyense growth by bacterial assemblages from the Bay of Fundy. J. Appl. Microbiol. 2002, 92, 706-716. [CrossRef] [PubMed]

40. Provasoli, L.; Carlucci, A. Algal Physiology and Biochemistry; Blackwell Scientific Publications: Oxford, UK, 1974; pp. 741-787.

41. Croft, M.T.; Lawrence, A.D.; Raux-Deery, E.; Warren, M.J.; Smith, A.G. Algae acquire vitamin B12 through a symbiotic relationship with bacteria. Nature 2005, 438, 90-93. [CrossRef] [PubMed]

42. Croft, M.T.; Warren, M.J.; Smith, A.G. Algae need their vitamins. Eukaryot. Cell 2006, 5, 1175-1183. [CrossRef] [PubMed] 
43. Guillard, R.; Keller, M. Dinoflagellates; Elsevier: Amsterdam, The Netherlands, 1962; pp. 229-239.

44. Harrison, P.; Waters, R.; Taylor, F. A broad spectrum artificial seawater medium for coastal and open ocean phytoplankton. J. Phycol. 1980, 16, 28-35. [CrossRef]

45. Cruz-López, R.; Maske, H. The Vitamin B1 and B12 required by the marine dinoflagellate Lingulodinium polyedrum can be provided by its associated bacterial community in culture. Front. Microbiol. 2016, 7, 560. [CrossRef] [PubMed]

46. Bolch, C.J.S.; Bejoy, T.A.; Green, D.H. Bacterial associates modify growth dynamics of the dinoflagellate Gymnodinium catenatum. Front. Microbiol. 2017, 8, 670. [CrossRef] [PubMed]

47. Aquino-Cruz, A.; Okolodkov, Y. Impact of increasing water temperature on growth, photosynthetic efficiency, nutrient consumption, and potential toxicity of Amphidinium carterae and Coolia monotis (Dinoflagellata). Revista Biología Marina Y Oceanografía 2016, 51, 565-580. [CrossRef]

48. Hughes, R. Membrane Glycoproteins. A Review of Structure and Function; Elsevier: Amsterdam, The Netherlands, 1976.

49. Klut, E.; Bisalputra, T.; Antia, N. Some cytochemical studies on the cell surface of Amphidinium carterae. Protoplasma 1985, 129, 93-99. [CrossRef]

50. Turner, S.; Pryer, K.M.; Miao, V.P.; Palmer, J.D. Investigating deep phylogenetic relationships among cyanobacteria and plastids by small subunit rRNA sequence analysis. J. Eukaryot. Microbiol. 1999, 46, 327-338. [CrossRef] [PubMed]

51. Lane, D. Nucleic Acid Techniques in Bacterial Systematics; John Wiley and Sons: Hoboken, NJ, USA, 1999; pp. 115-175.

52. Nash, E.A.; Nisbet, R.E.; Barbrook, A.C.; Howe, C.J. Dinoflagellates: A mitochondrial genome all at sea. Trends Genet. 2008, 24, 328-335. [CrossRef] [PubMed]

53. Barbrook, A.C.; Howe, C.J.; Kurniawan, D.P.; Tarr, S.J. Organization and expression of organellar genomes. Philos. Trans. R. Soc. Lond. B Biol. Sci. 2010, 365, 785-797. [CrossRef] [PubMed]

54. Nayak, B.; Karunasagar, I.; Karunasagar, I. Influence of bacteria on growth and hemolysin production by the marine dinoflagellate Amphidinium carterae. Mar. Biol. 1997, 130, 35-39. [CrossRef]

55. Soffer, N.; Gibbs, P.; Baker, A. Practical applications of contaminant-free Symbiodinium cultures grown on solid media. In Proceedings of the 11th International Coral Reef Symposium, Ft. Lauderdale, FL, USA, 7-11 July 2008; pp. 159-163.

56. Xiang, T.; Hambleton, E.; DeNofrio, J.; Pringle, J.; Grossman, A. Isolation of clonal axenic strains of the symbiotic dinoflagellate Symbiodinium and their growth and host specificity. J. Phycol. 2013, 49, 447-458. [CrossRef] [PubMed]

57. Rolinson, G.N. Forty years of beta-lactam research. J. Antimicrob. Chemother. 1998, 41, 589-603. [CrossRef] [PubMed]

58. Galkiewicz, J.P.; Kellogg, A. Cross-Kingdom Amplification Using Bacteria-Specific Primers: Complications for Studies of Coral Microbial Ecology. Appl. Environ. Microbiol. 2008, 74, 7828-7831. [CrossRef] [PubMed]

59. Harding, H.P.; Zhang, Y.; Ron, D. Protein translation and folding are coupled by an endoplasmicreticulum-resident kinase. Nature 1999, 397, 271-274. [PubMed]

60. Markovic, P.; Roenneberg, T.; Morse, D. Phased protein synthesis at several circadian times does not change protein levels in Gonyaulax. J. Biol. Rhythms 1996, 11, 57-67. [CrossRef] [PubMed]

61. Bachvaroff, T.R.; Concepcion, G.T.; Rogers, C.R.; Herman, E.M.; Delwiche, C.F. Dinoflagellate expressed sequence tag data indicate massive transfer of chloroplast genes to the nuclear genome. Protist 2004, 155, 65-78. [CrossRef] [PubMed]

62. Hackett, J.D.; Yoon, H.S.; Soares, M.B.; Bonaldo, M.F.; Casavant, T.L.; Scheetz, T.E.; Nosenko, T.; Bhattacharya, D. Migration of the plastid genome to the nucleus in a peridinin dinoflagellate. Curr. Biol. 2004, 14, 213-218. [CrossRef] [PubMed]

(C) 2017 by the authors. Licensee MDPI, Basel, Switzerland. This article is an open access article distributed under the terms and conditions of the Creative Commons Attribution (CC BY) license (http:/ / creativecommons.org/licenses/by/4.0/). 